\title{
Assessment of the fate and intensity of particulate matter associated with playgrounds in traffic- congested areas of yenagoa metropolis, Nigeria
}

\begin{abstract}
The health problems posed by Particulate Matter (PM) cannot be overemphasized. This research focused on the assessment and health risk of particulate matter of playgrounds within traffic congested area of Yenagoa Metropolis Nigeria. Levels of PM, metrological indicators and traffic count were measured at 7 locations (including a control station) using AEROCET 513 Portable Meter (Metone instrument). The PM value were determined for; $\mathrm{PM}_{10}\left(12.33-23.33 \mu \mathrm{g} / \mathrm{m}^{3}\right), \mathrm{PM}_{25}\left(17.00-31.67 \mu \mathrm{g} / \mathrm{m}^{3}\right), \mathrm{PM}_{40}\left(30.33-49.67 \mu \mathrm{g} / \mathrm{m}^{3}\right)$, $\mathrm{PM}_{70}\left(35.33-70.33 \mu \mathrm{g} / \mathrm{m}^{3}\right) \mathrm{PM}_{10}\left(51.00-108.00 \mu \mathrm{g} / \mathrm{m}^{3}\right)$, and Total Suspended Particulate Matter (TSP) ranging from $135.00-246.67 \mu \mathrm{g} / \mathrm{m}^{3}$. The control site indicated the lowest concentration of particulate matter $(\mathrm{p}<0.05)$, with no traffic count per minute. Moreover, the playgrounds that indicated the highest level of particulate matter similarly had the highest traffic count. Traffic count increased with corresponding increase in particulate matter level $(\mathrm{p}<0.05)$. This study, therefore, concludes that the emission of the playground is a reflection of vehicular traffic, dust scrub influenced by anthropogenic and meteorological factor.
\end{abstract}

Keywords: particulate matter, air-quality, playground, traffic congestion
Volume 4 Issue 6 - 2018

\author{
Binaebiye Seibokuro, ' Tariwari CN Angaye, ${ }^{2}$ \\ Odigo Konmeze 3 \\ 'School of Environment \& Life Sciences, University of Salford, \\ Nigeria \\ ${ }^{2}$ Department of Biological Sciences, Niger Delta University, \\ Nigeria \\ ${ }^{3}$ Department of Environmental Health, Collage of Health \\ Technology, Nigeria
}

\begin{abstract}
Correspondence: Tariwari CN Angaye, Department of Biological Sciences, Niger Delta University, Wilberforce Island,
\end{abstract} Bayelsa State, Nigeria, Email maktarry@yahoo.com

Received: November 20, 2018 | Published: December 20, 2018

\section{Introduction}

Suspended Particulate Matter (SPM) are minute atmospheric solid, liquid or gaseous aerosol, whose sources can be anthropogenic or lithogenic. ${ }^{1}$ The types of suspended particulate matter include fine particulate matter whose diameter ranges from $2.5 \mu \mathrm{m}$ and below, while the diameter of coarse particulate matter ranges from above 2.5$10 \mu \mathrm{m} .{ }^{2}$ Notwithstanding, the sub-kinds of particulate matter include but not limited to; suspended particulate matter (SPM), thoracic particles as well as respirable particles. ${ }^{1,3}$ The sources of atmospheric particulate matter vary and may depend on certain compounding environmental factors, whose fate is mostly influenced by some meteorological conditions. ${ }^{4}$ Major contributor of particulate matter emission may arise from the wear of vehicle components such as brakes and tires as well as suspension of road dust particles. Based on magnitude (i.e. fine and coarse SPM), the levels of SPM include; PM 1.0, PM 2.5 which are fine particulate; and PM 4.0, PM 7.0, PM 10 are coarse particulate matter. However, total aggregates of PM 1.0-PM10 makes up what is called total suspended particulate (TSP). The World Health Organisation (WHO), adduce PM1.0 as the deadliest (group 1 carcinogens) amongst all particulate matter due to their finest particles and ability to penetrate the lungs and bloodstream, thereby causing DNA mutation, heart attack and even infant mortality. ${ }^{2}$

Statistical data documented in literature amongst over 300,000 persons in 9 European countries in the year 2013 indicated no safe level of particulate, there was $22 \%$ lung cancer rate for increased concentration of $10 \mu \mathrm{g} / \mathrm{m}^{3}$ in PM10, and even $36 \%$ increase for PM 1.0. ${ }^{5}$ The United State Environmental protection Agency, ${ }^{2}$ has considered the particulate matter as one of the six criteria pollutants. ${ }^{2}$ In addition, US EPA through the U.S Clean Air Acts has established that the primary standard for human health protection for both $\mathrm{PM}_{10}$ at $150 \mu \mathrm{g} / \mathrm{m}^{3}$ and $\mathrm{PM}_{2.5}$ at $35 \mu \mathrm{g} / \mathrm{m}^{3}$ is 24 hours and $15 \mu \mathrm{g} / \mathrm{m}^{3}$ annually. ${ }^{6}$ Health risk studies of PM have shown that the particulate size plays an essential role on adverse effects caused by PM concentrations. ${ }^{6,7}$ For instance, studies show that children in proximity with higher PM concentration have a larger risk of developing allergies and asthma from the dust. ${ }^{6}$ Further studies have also shown that vehicular traffic density does not record the differences in PM toxicity between corresponding neighbourhoods; this therefore, implies that particulate chemistry plays a vital role on health effect. ${ }^{7,8}$ According to Krewski, ${ }^{9}$ exposure to the particulate matter has the potential to reduce the life expectancy of the population by 8.6 months. Globally, it has been established in the literature that particulate matter accounts for $3 \%$ of cardiopulmonary disease and $5 \%$ of lung cancer mortality. ${ }^{10}$

In addition, Several authors have documented in their studies that adverse health effects of particulate matter which includes several acute and chronic presentations like; chronic respiratory imperilment and cardiovascular diseases, lung dysfunction, emergency cases and infant mortality. ${ }^{11-14}$ In Yenagoa Metropolis, most playgrounds are located in schools aligning road with high vehicular traffic on daily bases. These playgrounds are usually sandy, dry and dusty with mosaic or no vegetation cover. In order to unravel these hazards, the health risk of SPM emission is hereby investigated.

\section{Material and method}

\section{Study area}

The study area (Yenagoa Metropolis) is the State Capital Territory of Bayelsa State, which lies Southernmost on the Nigeria Map. It has a population estimate of over 300,000 . Yenagoa forms part of the wetland of the Niger Delta Region, characterized by shallow aquifer and several networks of creeklets. It has two prevailing seasons, which are the dry and wet season. The dry season is windy and dusty with no precipitation, while wet season have high level of precipitation. ${ }^{4}$

\section{Sampling techniques and analysis}

\section{Sampling stations}

There are several playgrounds in Yenagoa metropolis. However, the sampling site (i.e. playgrounds), were selected based on their 
proximity to traffic congested areas and each of the playgrounds is in the same distance to the road where corresponding traffic count was taken. For the purpose of this investigation, seven randomly selected playgrounds including a comparison site (LX), which is a non-playground located outskirt the metropolis. The comparison site is used to establish the source of concentration that is seen outside of traffic congested area but to actually determine exactly how much contribution emitted from traffic, there is a need for a much more comprehensive network of comparison sites. Notwithstanding, the playground includes Agudama (LA), Akenpai (LB), Edepie (LC), Okutukutu(LD), Opolo (LE), Biogbolo (LD) and Kpansia (LF). The playgrounds were geo-referenced during the sampling with the aid of a portable Germin etrex Global Positioning System (GPS), with model number CZ 99052-20-Taiwan.

\section{Sampling procedure}

A six levelled $\left(\mathrm{PM}_{1.0}, \mathrm{PM}_{2.5}, \mathrm{PM}_{4.0}, \mathrm{PM}_{7.0}, \mathrm{PM}_{10}\right.$ and TSP $)$ monitoring of SPM, as well as meteorological indicators in six school playground of pupils in the peak of the wet season were assessed. In addition, a comparison site (garden) not known to be a playground was sampled. Sampling was carried out in triplicate within a radius of 10metres away from the middle of the playground to provide a representative characterisation of SPM loads within the playground at the time of sampling. Furthermore, the corresponding traffic count of each measured triplicate particulate concentration was recorded as well. During sampling, the probe of the meter faced the windward direction. The average of the triplicate samples was taken as the final reading. AEROCET 531 SPM metone meter was used for the sampling. When the meter is powered and the start button is switched on, the meter begins to vibrate, sampling last for approximately one Table I Meteorological indicators of the study area minute. At the end of the sampling, all results are displayed on the screen of the meter. Data were in triplicate for all stations.

\section{Statistical analysis}

Statistical analysis was carried out by using SPSS version 20 and the analysis of variance was used to fashion out the mean and standard deviation of the triplicate samples. Meanwhile, Duncan Multiple Range post Hoc tests was used to establish the degree of significance $(p=0.05)$ in the distribution of particulate matter and traffic count. In addition, the 2016 version of Microsoft and Excel package was used to plot charts where applicable based on mean values.

\section{Results}

Results on the meteorological indicators of the playgrounds are presented in Table 1. The mean values of temperature in the study area (LA-LF), ranges from $28.60-32.69^{\circ} \mathrm{C}$. There was a significant difference $(p<0.05)$ amongst the stations with exception of stations LD and LE which had no significant difference $(p>0.05)$ as presented in Table 1. Furthermore, the highest value of temperature was reported in station LC, while the lowest temperature was in station LD. It was also observed that the temperature of the comparison site (LX), was significantly different $(p>0.05)$ compared to the other stations in the study area (LA-LF). The mean values of relative humidity associated with the playgrounds (LA-LF) are presented in Table 1 . Results showed that values of relative humidity range from $49.36-65.26 \%$. With exception of stations LB and LC that had no significant difference $(p>0.05)$, there was a significant difference $(p<0.05)$ amongst the stations as presented in Table 1 . The highest and lowest values of relative humidity were reported in station LE, while lowest relative humidity was in station LA and LF respectively.

\begin{tabular}{|c|c|c|c|c|c|}
\hline Codes & Northings & Eastings & Temperature $\left({ }^{\circ} \mathrm{C}\right)$ & Rel. Humidity (\%) & Wind $(\mathrm{m} / \mathrm{s})$ \\
\hline LA & N04⒌ $48.7^{\|}$ & E06 $22^{\prime} 44.8^{\prime \prime}$ & $31.17 \pm 0.23 \mathrm{e}$ & $51.57 \pm 0.08 \mathrm{~b}$ & $1.49 \pm 0.28 c$ \\
\hline LB & N045ㄱ $24.5^{\prime \prime}$ & E06 $2 I^{\prime} 52.3^{\prime \prime}$ & $30.50 \pm 0.4 \mathrm{Id}$ & $49.36 \pm 0.04 a$ & $1.90 \pm 0.10$ \\
\hline LC & N0456 $54.3^{\prime \prime}$ & E06 $20^{\prime} 52.3^{\prime \prime}$ & $32.69 \pm 0.03 f$ & $48.43 \pm 0.04 a$ & $0.7 I \pm 0.15 \mathrm{a}$ \\
\hline LD & N0456 $28.3^{\prime \prime}$ & E06 $1942.7^{\prime \prime}$ & $29.70 \pm 0.52 c$ & $64.49 \pm 0.03 d$ & $2.16 \pm 0.18 d$ \\
\hline LE & N0456 $24.3^{\| \prime}$ & E06 $19^{\prime} 23.4^{\prime \prime}$ & $29.50 \pm 0.03 b c$ & $65.26 \pm 0.02 d$ & $1.10 \pm 1.00 \mathrm{~b}$ \\
\hline LF & N045ㄴ $47.3^{\|}$ & E06 $18^{\prime 1} 19.3^{\prime \prime}$ & $28.92 \pm 0.44 a b$ & $61.33 \pm 1.52 c$ & $2.73 \pm 0.21 \mathrm{e}$ \\
\hline LX & N0458 $24.4^{\|}$ & E06 $20^{\circ} 37.4^{\prime \prime}$ & $28.60 \pm 0.52 a$ & $61.00 \pm 1.00 c$ & $0.99 \pm 0.17 \mathrm{ab}$ \\
\hline
\end{tabular}

Data expressed as mean \pm standard deviation, the difference in alphabetical subscript indicate the significant difference

In addition, the relative humidity of the comparison site (LX), was significantly $(\mathrm{p}<0.05)$ low compared to the other stations in the study area (LA-LF). As presented in Table 1, the mean values of wind speed associated with the playgrounds (LA-LF), had values ranging from $0.71-2.73 \mathrm{~m} / \mathrm{s}$. Stations LF and LC had the highest and lowest values of wind speed respectively. In addition, there was a significant difference $(p<0.05)$ amongst wind speed levels in the playgrounds with exception of stations LD and LE which had no significant difference ( $p>0.05)$, as shown in Table 1. Furthermore, the highest level of wind speed was reported in station LF, while the lowest temperature was in station LC. With exception to station LC, the wind speed of the comparison site $(\mathrm{LX})$, was significantly $(\mathrm{p}<0.05)$ lower compared to the other stations in the study area (LA - LF). Figure 1, presents the spatial mean levels of $\mathrm{PM}_{1.0}$ particulate matter ranges from $12.33-23.33 \mu \mathrm{g} / \mathrm{m}^{3}$, with a corresponding traffic count ranging from 3.00-15.33 count/minute. It was also observed that the playgrounds with the highest (LF) and lowest (LE) levels of particulate matter, were similar in trend for traffic counts as well ( $p>0.05)$. With exception of station LE and the comparison site (LX), there were significant differences amongst all the stations $(\mathrm{p}<0.05)$ for $\mathrm{PM}_{10}$. There was significant spatial variation in traffic count, with no recorded traffic counts in the comparison site.

Figure 2 presents the mean concentration and corresponding traffic counts of $\mathrm{PM}_{2.5}$ particulate matter. Mean values of $\mathrm{PM}_{2.5}$ particulate matter ranges from $17.00-31.67 \mu \mathrm{g} / \mathrm{m}^{3}$, with a corresponding traffic count range of $2.67-10.00$ count/minute. The highest level of $\mathrm{PM}_{25}$ particulate matter and traffic count were reported in station LF, while lowest level was reported in station LE. Comparatively, a much lower value of $\mathrm{PM}_{25}$ particulate matter was reported in the comparison site with no traffic count. Notwithstanding, there were spatial significant differences amongst the sampling station $(\mathrm{p}<0.05)$, including the comparison site. Compared to the World Health Organisation (WHO) limit of $25 \mu \mathrm{g} / \mathrm{m}^{3}$, only the playgrounds LC and LF had exceeding value. 
However, based on the National Air Quality Standard only station LF had a value exceeding the threshold value of $30 \mu \mathrm{g} / \mathrm{m}^{3 .}$ The spatial mean background levels of $\mathrm{PM}_{4.0}$ in the study area ranged from 30.33$49.67 \mu \mathrm{g} / \mathrm{m}^{3}$, with a corresponding traffic count of $1.33-9.67$ counts/ minute (Figure 3). The highest and lowest values of $\mathrm{PM}_{40}$ particulate matter and traffic count were similarly reported in stations LF and LD respectively (Figure 3 ). In addition, the comparison site indicated the lowest level of $\mathrm{PM}_{40}$ particulate matter, with no recorded traffic count (Figure 3). Comparatively, there were significant differences $(\mathrm{p}<0.05)$ amongst the levels of $\mathrm{PM}_{40}$ and traffic count in all stations, including the comparison site. Figure 4 presents the mean concentrations of $\mathrm{PM}_{70}$ particulate matter and its corresponding traffic count. Values of particulate ranging from $35.33-70.33 \mu \mathrm{g} / \mathrm{m}^{3}$ was reported with a corresponding traffic count of 2.00-11.33 count/minute. While the comparison site indicated the lowest level of $\mathrm{PM}_{70}$ particulate matter with zero traffic count, the highest level and lowest level of $\mathrm{PM}_{7.0}$ particulate matter and traffic counts were similarly reported in station LF and LD respectively (Figure 4). Notwithstanding, there were significant differences between some of the sampling stations $(\mathrm{p}<0.05)$, including the comparison site

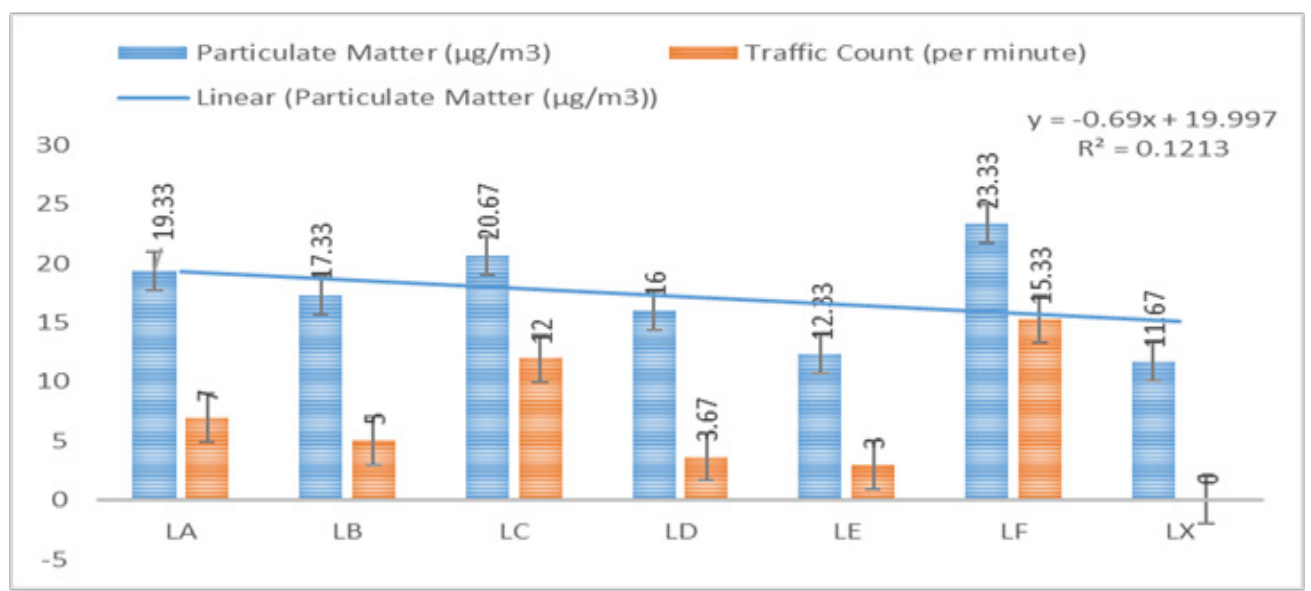

Figure I Mean Background of $\mathrm{PM}_{1.0}$ in the Study area.

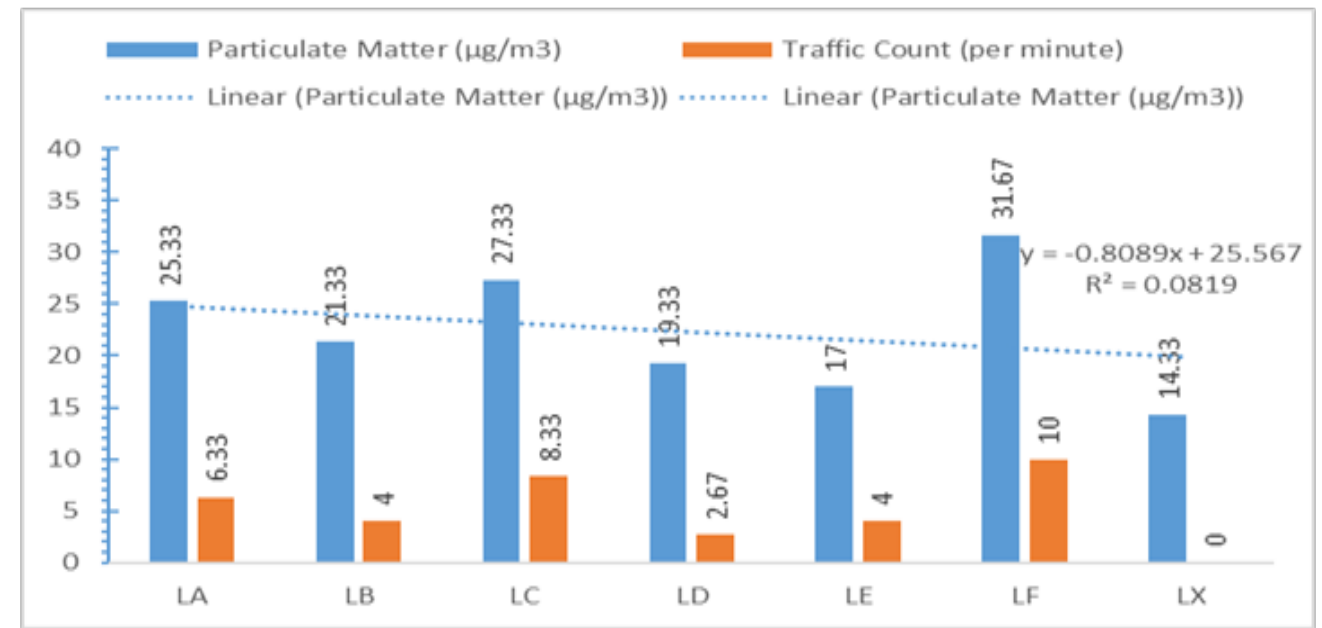

Figure 2 Mean Background of $\mathrm{PM}_{2.5}$ in the Study area.

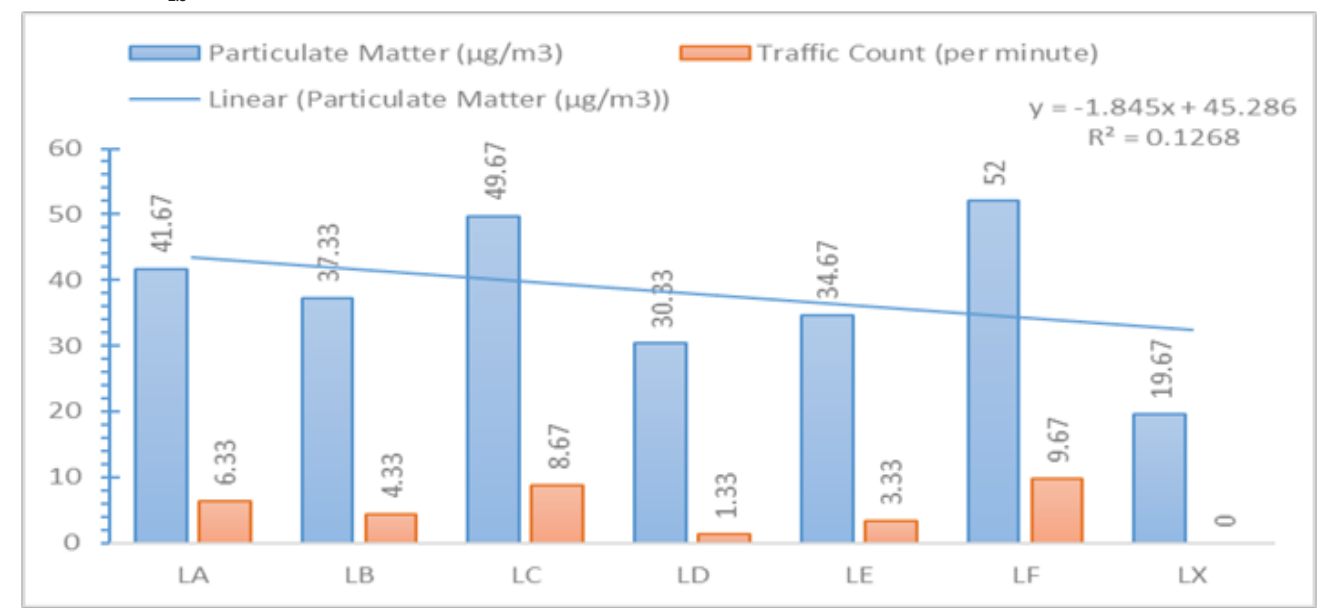

Figure 3 Mean Background of $\mathrm{PM}_{4.0}$ in the Study area. 
The levels of $\mathrm{PM}_{10}$ particulate matter ranges from 51.00 $108.00 \mu \mathrm{g} / \mathrm{m}^{3}$, with a corresponding traffic count of $3.67-12.33 \mathrm{count} /$ minute (Figure 5). The comparison site indicating the lowest level with no traffic count. In addition, the highest and lowest level of $\mathrm{PM}_{10}$ and corresponding traffic count were similarly reported in stations LF and LD respectively (Figure 5). Only the comparison site (LX), and station LD has no significant difference $(\mathrm{p}>0.05)$. Compared to WHO limit of $50 \mu \mathrm{g} / \mathrm{m}^{3}$ all of the playgrounds was above the limit, however, when compared to the National air quality limit only station LF exceeded the limit of $100 \mu \mathrm{g} / \mathrm{m}^{3}$. The mean background level of Total Suspended Particulate Matter (TSP) ranges from 135.00-246.67 $\mu \mathrm{g} /$ $\mathrm{m}^{3}$, with corresponding traffic range of 3.00-12.00 count/minute (Figure 6). A relatively lower value of TSP, with no traffic count, was reported in the comparison site (Figure 6). In addition, the highest and lowest level of TSP and traffic count were reported in station LF and LD respectively. Comparatively, there were significant differences amongst all the stations including the comparison site.



Figure 4 Mean Background of $\mathrm{PM}_{7.0}$ in the Study area.

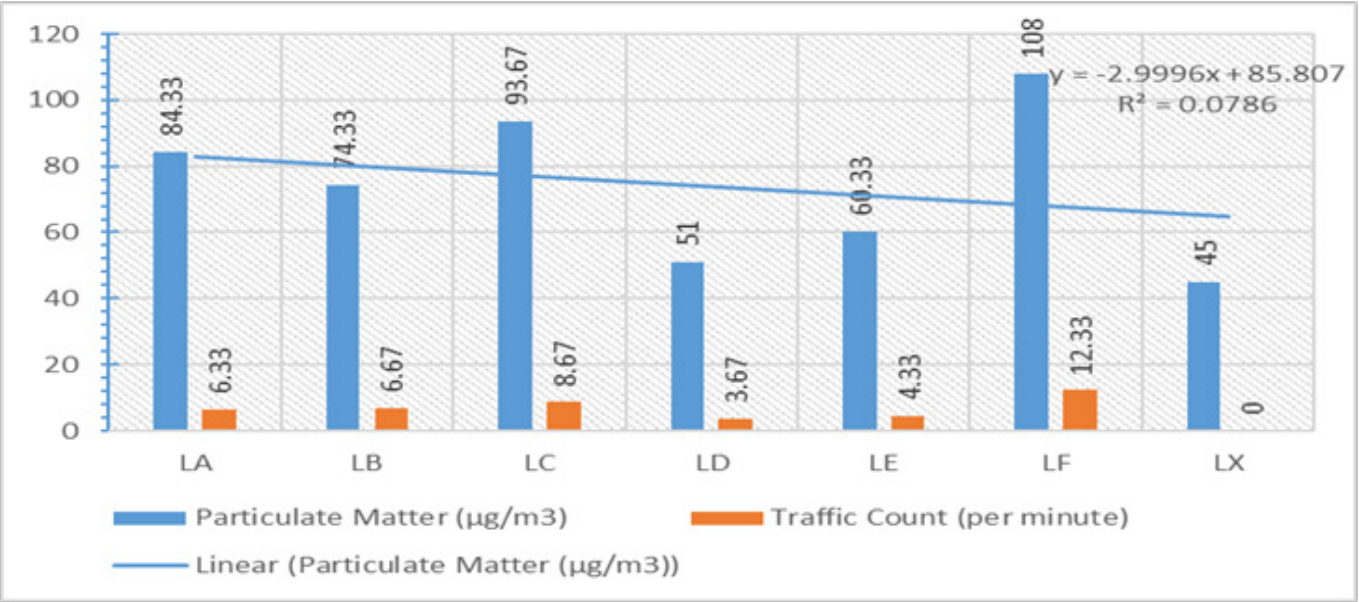

Figure 5 Mean Background of $\mathrm{PM}_{10}$ in the Study area.

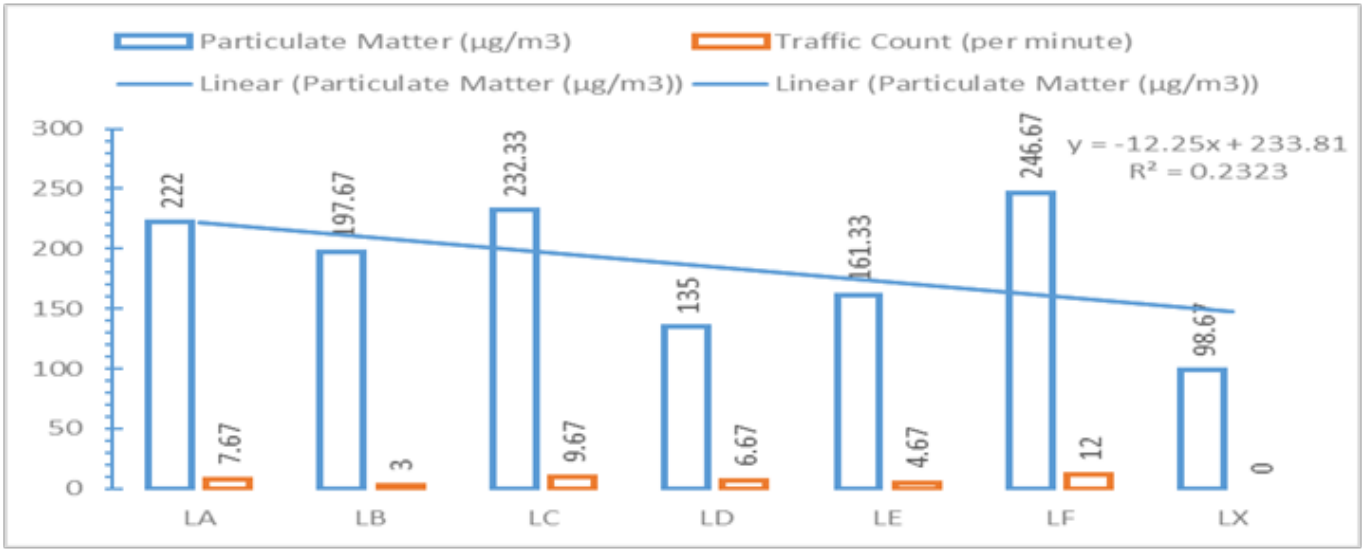

Figure 6 Mean Background of Total Suspended Particulate in the Study area. 


\section{Discussion}

A variety of compounding factors may have contributed to the intensity of particulate matter in the study area. For instance, some meteorological parameters, ${ }^{15}$ and vehicular emissions, ${ }^{16}$ play vital roles in determining the fate and intensity of particulate matter emission. As documented in literature the major factors that affect particulate matter emission include; domestic emission, external sources, and the meteorological indicators. ${ }^{17}$ This includes, the dry, sandy and dusty nature of the playground may be another major contributor, which is a typical characteristics of tropical region. An earlier study by Jayamurugan et al., ${ }^{15}$ had established that temperature, relative humidity, wind speed and wind direction may have major influence the fate of air pollutants including particulate matter. ${ }^{18}$

As established in the literature by several authors, ambient air quality in major cities across Nigeria's has been impaired by the emission of Particulate Matter. Total Suspended Particulate ranging from $1033-40000 \mu \mathrm{g} / \mathrm{m}^{3}$ in an industrial area of Lagos city. ${ }^{19}$ In Maiduguri and Abuja PM10 ranging from 118.3-132.0 $\mu \mathrm{g} / \mathrm{m} 3$ was reported. ${ }^{20}$ In some randomly selected Lagos levels of $\mathrm{PM}_{25}$ and PM10 were 27 and $69 \mu \mathrm{g} / \mathrm{m}^{3}$ respectively. ${ }^{21}$ In Abuja and Aba, the level of $\mathrm{PM}_{2.5}$ was $14 \mu \mathrm{g} / \mathrm{m}^{3}$ and $102 \mu \mathrm{g} / \mathrm{m}^{3}$ while $\mathrm{PM}_{10}$ level was reported as $38 \mu \mathrm{g} / \mathrm{m}^{3}$ and $553 \mu \mathrm{g} / \mathrm{m}^{3}$. The reports of Obioh et al. ${ }^{22}$ has revealed the $\mathrm{PM}_{10}$ concentration of $38 \mu \mathrm{g} / \mathrm{m}_{3}$ in Abuja and $553 \mu \mathrm{g} / \mathrm{m}^{3}$ in Aba, and $\mathrm{PM}_{2.5}$ concentration varying between $14 \mu \mathrm{g} / \mathrm{m}^{3}$ in Abuja and 102 $\mu \mathrm{g} / \mathrm{m} 3$ in Aba. Ideriah et al. ${ }^{23}$ have measured TSP concentration range of $19.0-1677.9 \mu \mathrm{g} / \mathrm{m}^{3}$ in five communities in south-eastern Nigeria. A study by Ohimain et al. ${ }^{24}$ at a palm oil processing industry in Elele, Rivers recorded the TSP values between 1634 and $7853 \mu \mathrm{g} / \mathrm{m}^{3}$. These reported PM values were greater than the USEPA (2008) daily and annual mean standards of 150 and $50 \mu \mathrm{g} / \mathrm{m}^{3}$, respectively. A study at a steel and iron industry in Lagos by Owoade for PM10 and $\mathrm{PM}_{25}$ revealed concentration ranges of $86-8765 \mu \mathrm{g} / \mathrm{m}^{3}$ and $10-462 \mu \mathrm{g} / \mathrm{m}^{3}$, respectively. The unusually high concentrations of these PM size fractions may be harmful to the public, especially the residents living around the vicinity of the steelworks industry.

Notwithstanding, the temperature range of this study is in tandem to study of Angaye et al. ${ }^{4}$ in Yenagoa metropolis, with values ranging from $31.33-33.76$ and $27.91-28.48^{\circ} \mathrm{C}$, in dry and wet seasons respectively. Higher temperature is characterized by lower relative humidity ${ }^{4}$ however, temperature variability is adduced to spatial distribution, seasons, as well as day or night..$^{15}$ The values of relative humidity in this study are comparable to the recent investigation in the study area whose values ranged from $57.24 \pm 7.16-61.84 \pm 5.66$ in the dry season, and $82.93 \pm 3.44-86.58 \pm 4.11 \%$ wet season. ${ }^{4}$ Nigerian climate is characterized by two predominant seasons, which are the dry and wet season the relative humidity is usually lower during the dry season. ${ }^{4}$ As such, relative humidity has also been found to have a negative correlation with the emission of particulate matter according to the studies of Bhaskar and Mehta, ${ }^{18}$ According to Jayaraman, ${ }^{15}$ particulate matter has been found to have an inverse correlation with relative humidity, an increase in relative humidity have negative correlation with particulate matter emission. ${ }^{25}$

Varying degree of wind speed was reported in the various playgrounds. Notwithstanding, the level of wind speed is comparable to a recent study whose values ranged from $1.22 \pm 0.45-3.49$ in the dry season and $0.73-5.25 \mathrm{~m} / \mathrm{s}$ in the wet season. ${ }^{4}$ Playground LF that recorded the highest levels of particulate matter also recorded the highest wind speed. The studies of Wang and Ogawa, ${ }^{17}$ indicated negative correlation in a particulate matter whose wind speed less than $3 \mathrm{~m} / \mathrm{s}$ and positive correlation in a particulate matter whose wind speed greater than $3 \mathrm{~m} / \mathrm{s}$. Wind speed limits ranging from $0.51-1.8 \mathrm{~m} / \mathrm{s}$ are usually regarded as calm wind. ${ }^{26}$ Notwithstanding, a low wind speed can blow have less spread of pollutants compared to wind speed with high intensity. ${ }^{17}$

As reported by Angaye and Abowei (2018) in a recent study on the evaluation of particulate matter $\left(\mathrm{PM}_{1.0}-\mathrm{PM}_{10}\right)$ around dumpsite in the study area showed that values of $\mathrm{PM}_{1.0}$ ranges from $17.04-32.81 \mu \mathrm{g} / \mathrm{m}^{3}$ in dry and $14.03-19.03 \mu \mathrm{g} / \mathrm{m}^{3}$ in the wet season. In the same study, the values of PM2.5 were $23.11-44.87$ and $20.41 \pm 0.52-32.07 \pm 3.35 \mu \mathrm{g} /$ $\mathrm{m}^{3}$ in the dry and wet seasons respectively. Other speciation's of particulate matter in dry and wet seasons respectively were; PM 4.0 $\left(32.03-62.80\right.$ and $\left.29.82-50.54 \mu \mathrm{g} / \mathrm{m}^{3}\right)$, PM $7.0(75.01-197.11$ and $\left.45.17-71.27 \mu \mathrm{g} / \mathrm{m}^{3}\right)$, PM10 $\left(109.40-305.10\right.$ and $\left.56.53-93.07 \mu \mathrm{g} / \mathrm{m}^{3}\right)$, and Total Suspended Particulate which ranged from 227.66-597.26 and $2.40-172.23 \mu \mathrm{g} / \mathrm{m}^{3}$ in dry and wet season respectively. In addition, the study also indicated higher values of particulate matter in the dry season, compared to the wet season with significant difference $(\mathrm{p}<0.05)$.

A study carried out by Obioh using a 'Gent' stacked filter on the atmospheric particulate matter in Nigeria Megacities shows the mean values for PM10 for Aba, Abuja, Lagos, Kano, Maiduguri and Port-Harcourt are 550, 35, 87, 340,246 and $130 \mathrm{mg} / \mathrm{m}^{3}$ respectively. Whereas for PM2.5 the mean values were 100, 14, 25, 67, 20 and $30 \mathrm{mg} / \mathrm{m}^{3}$ respectively for Aba, Abuja, Lagos, Kano, Maiduguri, and Port-Harcourt. While the values for PM2.5 were within the guideline limit for WHO, The only value exceeding WHO limit with regards to the daily mass loads was the PM10 for Abuja Metropolis.

In the same study, varieties of factors such as; anthropogenic activities, weather and sampling time were being attributed to the increased level in the concentration of $\mathrm{PM}_{10}$ and $\mathrm{PM}_{2.5}$ particulate fractions. Abuja and Maiduguri concentration values recorded PM2.5 within the WHO 24-h threshold limit guideline of $25 \mathrm{mg} / \mathrm{m}^{3}$. Whereas the average concentration of $\mathrm{PM}_{2.5}$ at Abuja $\left(14 \mathrm{mg} / \mathrm{m}^{3}\right)$ and Maiduguri $\left(20 \mathrm{mg} / \mathrm{m}^{3}\right)$, is within the WHO daily threshold limit due to the fact that $\mathrm{PM}_{25}$ emissions are essentially from anthropogenic activities, ${ }^{27}$ of which $\mathrm{PM}_{2.5}$ sources of industrial activities is very low in Maiduguri and non-existent in Abuja, therefore, it was speculated that wood / biomass and vehicular emissions may be justified primarily for the low mean values of $\mathrm{PM}_{2.5}$ mass attained in those cities. Generally, with exception of particulate collected in Abuja, $\mathrm{PM}_{10}$ average concentration investigated in all sites were found to be higher than the recommended WHO 24-h threshold limit guideline of $50 \mathrm{mg} / \mathrm{m}^{3}$. In addition, average levels of $\mathrm{PM}_{10}$ amongst the megacities in order of activities for PM10 were; Aba $>$ Kano $>$ Maiduguri $>$ Port Harcourt $>$ Lagos $>$ Abuja, while $\mathrm{PM}_{2.5}$ were; Aba $>$ Kano $>$ Port Harcourt $>$ Lagos $>$ Maiduguri $>$ Abuja). The emission levels of $\mathrm{PM}_{10}$ did not follow a similar trend compared to PM2.5.

Owoade et al. carried out another study on chemical compositions and source identification of particulate matter using a low volume GENT sampler equipped with a stacked filter unit (SFU). In the study, samples of fine $\left(\mathrm{PM}_{25}\right)$ and Coarse $\left(\mathrm{PM}_{25-10}\right)$ of 200 samples stations were collected. Results of the studies showed that the mass concentration of the sampled fine and coarse PM fraction ranges between $14.4-986.5 \mu \mathrm{g} / \mathrm{m}^{3}$ and $11.2-3250 \mu \mathrm{g} / \mathrm{m}^{3}$ for PM 2.5 and 
PM10 respectively. These values surpassed the allowable daily limit (NAAQS) of $35 \mu \mathrm{g} / \mathrm{m}^{3}$ for $\mathrm{PM}_{25}$ and $150 \mu \mathrm{g} / \mathrm{m}^{3}$ for PM10. The study also identified the following sources of emission (for both fine and coarse fractions) in their order of activities; cooking coal (83\%), soil $(10 \%)$, metallurgical industry $(6 \%)$, electronic waste $(1 \%)$ for fine fraction: For coarse fraction values were; metallurgical production and electronic waste (53\%), suspended materials $(28 \%)$, soil (18\%), and galvanized steel with other metalloid was (1\%).

The contamination and Health Risk of suspended particulate matter (SPM) in Uyo, Metropolis of the Niger Delta, Nigeria (with regards to trace metal) which share a similar characteristic with Yenagoa metropolis was also investigated by Moses and Orok. ${ }^{28}$ The levels of particulates with regards to levels of emission were; $\mathrm{Fe}>\mathrm{Cu}>\mathrm{Zn}>\mathrm{Ni}>\mathrm{Cr}>\mathrm{Al}>\mathrm{Pb}>\mathrm{Co}>\mathrm{Ti}$. While mean enrichment factor was highest and lowest for Copper and Cobalt respectively for the spatial distribution. Based on Pearson correlation, there were strong positive correlations between $\mathrm{Fe} / \mathrm{Co}, \mathrm{Pb} / \mathrm{Ni}, \mathrm{Co} / \mathrm{Cr}, \mathrm{Al} / \mathrm{Co}$ and $\mathrm{Cu} / \mathrm{Ti}$. The major trace elements associated with the dust particles were; $\mathrm{Fe}$ $(11.65-21.00 \mathrm{mg} / \mathrm{kg}), \mathrm{Cu}(11.65-21.00 \mathrm{mg} / \mathrm{kg})$ and $\mathrm{Zn}(15.05-18.20 \mathrm{mg} /$ $\mathrm{kg}), \mathrm{Ni}(1.35-4.05 \mathrm{mg} / \mathrm{kg}), \mathrm{Cr}(0.80-1.35 \mathrm{mg} / \mathrm{kg}), \mathrm{Al}(0.50-10.5 \mathrm{mg} /$ $\mathrm{kg}), \mathrm{Co}(0.05-0.25), \mathrm{Pb}(0.55-0.77 \mathrm{mg} / \mathrm{kg})$ and $\mathrm{Cd}(0.25-1.00 \mathrm{mg} / \mathrm{kg})$ Also, other mean concentration of other elemental emissions were; sulphate $(911.5-1343.5 \mathrm{mg} / \mathrm{kg})$, phosphates $(15.9-98.8 \mathrm{mg} / \mathrm{kg})$, and nitrate $(46.7-1371 \mathrm{mg} / \mathrm{kg})$. In addition, the calculated Target Hazard Quotient values of $\mathrm{Fe}(2.30-2.43)$ and $\mathrm{Cu}(0.24-0.44)$ were highest. The elemental contribution to the atmosphere is due to anthropogenic activities like welding, construction activities, smoking, automobile wear and emission. ${ }^{29}$

According to de Hartog et al., ${ }^{30}$ the effects of fine and ultrafine Particulates on Cardio respiratory indicators in the ageing group, was investigated in four countries (Netherlands, Germany and Finland), between 1998-1999 during the winter period. Results showed that the probabilities ratios relating symptoms to air pollution, exposure rate, respirational toxicities, and meteorological variables, were mostly in tandem across the cities. While there was no relationship between chest pain and air pollution, increase levels of $\mathrm{PM}_{25}$ was positively linked with breath seizures. The study concluded that $\mathrm{PM}_{2.5}$ was strongly linked to cardio respiratory symptoms compared to ultrafine particles. Another study in India was in tandem, indicating that particulate matter is associated with cardiovascular diseases. ${ }^{31}$

\section{Conclusion}

Environmental Risk Assessment of Particulate Matter associated with some school playgrounds within the traffic-congested area of Yenagoa Metropolis Nigeria was assessed. Unfortunately, most of the playgrounds had significant levels of particulate matter emission (PM1.0-PM10). The levels of particulate matter were influenced by dust scrubbing and proximity to vehicular emission. In addition, the meteorological indicators like temperature, relative humidity and wind speed as well as dust particles from the playgrounds also influenced the fate of particulate matter emission in the study area. The level of particulate matter emission is a reflection of anthropogenic activities, which must be ameliorated in order to avert adverse effects.

\section{Acknowledgments}

None.

\section{Conflicts of interest}

The author(s) declares that there is no conflict of interest.

\section{References}

1. Brown JS, Gordons T, Price O, et al. Thoracic and Reparable Particulate definition for Human Health Risk Assessment. Part Fibre Toxicol. 2013;10:12

2. USEPA-United States Environmental Protection Agency. Air Quality Criteria for Particulate Matter; EPA/600/P-99/002aF; USEPA-United States Environmental Protection Agency: Washington, DC, USA, 2004; p. 900 .

3. Lingan BA, Poyyamoli G, Chandra UB. Assessment of Air Pollution and Its Impacts near Municipal Solid Waste Dumping Site, Kammiyampet, Cuddalore, India. International Journal of Innovative Research in Science, Engineering and Technology. 2014;3(5):12588- 12593.

4. Angaye TCN, Abowei JFN. Evaluation of suspended particulate matter (SPM) around municipal solid waste dumpsites in yenagoa metropolis, Nigeria. MOJ Toxicol 2018;4(2):54-57.

5. Ole Raaschou Nielson. Air pollution and Lung Cancer Incidence in 17 European Cohort: Prospective analysis from the European Study of Cohorts for Air Pollution Effects. Lancet. 2013;14(9):813-822.

6. Vallius M. Characteristics and sources of fine particulate matter in urban air. National Public Health Institute, Finland: Helsinki; 2005.

7. Vallius MJ, Ruuskanen J, Mirme A, et al. Concentrations and estimated soot content of PM1, PM2. 5, and PM10 in a subarctic urban atmosphere. Environmental science \& technology. 2000;34(10):1919-1925.

8. Hosiokangas J, Vallius M, Ruuskanen J, et al. Resuspended dust episodes as an urban air-quality problem in subarctic regions. Scand $J$ Work Environ Health. 2004. p. 28-35.

9. Krewski D. Evaluating the effects of ambient air pollution on life expectancy. 2009;360:413-415.

10. Fang Y, Naik V, Horowitz LW, et al. Air pollution and associated human mortality: the role of air pollutant emissions, climate change and methane concentration increases from the preindustrial period to present. Atmos Chem Phys. 2013;13:1377-1394.

11. Samoli E, Peng R, Ramsay T, et al. Acute effects of ambient particulate matter on mortality in Europe and North America: results from the APHENA Study. Environ Health Perspect. 2008;116(11):1480.

12. Halonen JI, Lanki T, Tuomi TY, et al. Particulate air pollution and acute cardiorespiratory hospital admissions and mortality among the elderly. Epidemiology. 2009;20:143-153.

13. Guaita R, Pichiule M, Mate T, et al. Short-term impact of particulate matter (PM2.5) on respiratory mortality in Madrid. Int $J$ Environ Health Res., 2011;21:260-274.

14. Perez L, Tobías A, Querol X, et al. Saharan dust, particulate matter and cause-specific mortality: a case-crossover study in Barcelona (Spain). Environ Int. 2012;48:150-155.

15. Jayaraman NG. Air Quality and Respiratory Health in Delhi. Environ Monit Assess. 2007;135:313-325.

16. Araújo IPS, Costa DB, Moraes RJB. Identification and Characterization of Particulate Matter Concentration at Construction Jobsites. Sustainability. 2014;6(11):7666-7688.

17. Wang J, Ogawa S. Effects of Meteorological Conditions on PM2.5 Concentrations in Nagasaki, Japan. Int J Environ Res. Public Health. 2015;12:9089-9101.

18. Bhaskar BV, Mehta VM. Atmospheric pollutants and their relationship with meteorology in Ahmeddabad". Aerosols and Air quality Research. 2010;10(4):301-315

19. Oluyemi EO, Asubiojo OI, Oluwole AF, et al. Elemental concentrations and source identification of air particulate matter at a Nigerian site: A 
preliminary study. J Radioanal Nucl Chem. 1994;179(2):187-194.

20. Taiwo AM, Arowolo TA, Abdullahi KI, et al. Particulate Matter Pollution in Nigeria: A review. Proceedings of the 14th International Conference on Environmental Science and Technology Rhodes, 2015.

21. Owoade OK, Fawole OG, Olise FS, et al. Characterization and source identification of airborne particulate loadings at receptor site-classes of Lagos mega-city, Nigeria. J Air \& Waste Managt Assoc. 2013;63:10261029.

22. Obioh IB, Ezeh GC, Abiye OE, et al. Atmospheric particulate matter in Nigerian megacities. Toxicological \& Environmental Chemistry. 2013;95(3):379-385.

23. Ideriah TJK, Braide SA, Fekarurhobo G, et al. Determination of indoor and outdoor concentrations of suspended particulate matter in Southeastern Nigeria. Ghana J Sci. 2001;41:23-27.

24. Ohimain EI, Izah SC, Abah SO. Air Quality Impacts of Smallholder Oil Palm Processing in Nigeria. J Environ Protect 4. 2013. p. 83-98.

25. Giri D, Murthy K, Adhikary PR. The influence of meteorological conditions on $\mathrm{PM}_{10}$ concentrations in Kathmandu Valley. International Journal of Environmental Research. 2008;2(1):49-60.
26. Weli VE, Adekunle O. Air Quality in the Vicinity of a Landfill Site in Rumuolumeni, Port Harcourt, Nigeria. Journal of Biotechnol Res. 2014;4(1):17-23.

27. Asubiojo OI, Obioh IB, Oluyemi EA, et al. Elemental Characterization of Airborne Particulates at Two Nigerian Locations during the Harmattan Season. Journal of Radio-Analytical and Nuclear Chemistry. 1993;167(2):283-293.

28. Moses EA, Orok UB. Contamination and Health Risk Assessment of Suspended Particulate Matter in Uyo, Niger Delta, Nigeria. Journal of Scientific Research and Report. 2015;6(4):274-286.

29. Atiemo SM, Ofuso FG, Kuranchie Mensah H, et al. Contamination assessment of heavy metals in road dust from selected roads in Accra, Ghana. Research Journal of Environmental and Earth Sciences. 2011;3(5):473-480.

30. de Hartog JJ, Hoek G, Peters A, et al. Effects of Fine and Ultrafine Particles on Cardiorespiratory Symptoms in Elderly Subjects with Coronary Heart Disease. Am J Epidemiol. 2002;157(7):613-623.

31. Mohanraj R, Azeez PA. Health effects of airborne particulate matter and the Indian scenario. Current Science. 2004;87(6):741- 748. 